\title{
Al'Ad̂̂lah \\ STRATEGI KOMUNIKASI POLITIK PARTAI KEBANGKITAN BANGSA (PKB) KABUPATEN JEMBER MENJELANG PEMILUKADA JAWA TIMUR 2018
}

\author{
Muhamad Farhan \\ Fakultas Dakwah IAIN Jember \\ muhammadfarhan@gmail.com
}

\section{Abstract}

Indonesia is one of the countries that embraces the system of democratic government. In a democratic state the people have sovereignty, this is done to ascertain who deserves to be a leader. The Party is an organization that represents the people and means of public participation to participate. Electoral parties compete for leadership seats (power) by strategizing to win them. Elections (elections) is the process of electing people to fill positions within government. The positions are diverse, ranging from the President, People's Representatives at various levels of government, to the Village Head. Elections as a means to participate in the people persuasively (not forced) to the government, so as to realize the principles of democracy in the implementation. Election is a means for political parties to place their cadres in strategic positions in government either executive (President, Governor, Regent, Mayor, etc.) or legislative (Regency, Provincial and Central DPRD) to seize power, not to mention Partai Kebangkitan Bangsa (PKB) Jember district in the face of elections East Java area. various pilitical communication strategies are used to hook as many constituens for the achievment of goals. The formulation of the problem in this Thesis is: How is the communication strategy of the Partai Kebangkitan Bangsa (PKB) of Jember Regency ahead of the election of General Head of Region (Pemilukada) of East Java 2018. The purpose of this research is to describe the communication strategy used by the Partai Kebangkitan Bangsa (PKB) of Jember Regency ahead of the elections of Regional Head (Pemilukada) of East Java 2018 to get the constituents from Jember society which is quite diverse. This research use desciptive qualitative approach. With data collection method of observation and documentation. The research concludes that the Partai Kebangkitan Bangsa (PKB) of Jember Regency divides its political communication strategy according to age ie political communication among young people and political communication among parents. Political communication among youth is done through the program of open together, coffee with PKB Jember, and halal bihalal. Whereas political communication among parents is 
implemented through the program of maintaining and maintaining the intensity of communication with leaders of both structural figures such as senior officials of an institution or mass organization or culture such as public figure.

\section{Kata Kunci : Strategi, Komunikasi dan Partai Politik}

\section{Pendahuluan}

Negara Indonesia adalah negara demokrasi. Dalam Negara demokrasi rakyat memiliki kedaulatan dilaksanakan untuk memastikan siapa yang pantas menjadi pemimpin untuk negara Indonesia. Partai merupakan organisasi yang mewakili rakyat dan sarana peran masyarakat untuk berpartisipasi. Partai yang ikut dalam pemilu bersaing untuk memperebutkan kursi kepemimpinan (kekuasaan) dengan melakukan strategi untuk memenangkannya. Pemilihan Umum (Pemilu) adalah proses pemilihan orang-orang untuk mengisi jabatan-jabatan didalam pemerintahan. Jabatan-jabatan tersebut beraneka-ragam, mulai dari Presiden, Wakil Rakyat diberbagai tingkat pemerintahan, sampai Kepala Desa. Pemilu sebagai sarana untuk berpartisispasi rakyat secara persuasif (tidak memaksa) kepada pemerintah, sehingga benar mewujudkan prinsip demokrasi dalam pelaksanaannya.

Perubahan perpolitikan di Indonesia semenjak jatuhnya rezim Soeharto karena telah memberikan ruang sebebas-bebasnya kepada masyarakat untuk menyampaikan segala aspirasinya, hal ini ditandai dengan lahirnya era reformasi, dimana Indonesia menjadi negara yang kian menghargai hak-hak politik warga negaranya terutama dalam hal memilih peminpin. kepemimpinan sebelumnya yang bersifat sentralik diubah menjadi desentralik dalam artian pemerintah pusat memberikan wewenang kepada daerahnya masing-masing untuk memilih kepala daerah dan wakilnya. selain itu juga memberikan ruang demokrasi politik lokal menjadi terbuka dan bebas dalam menentukan pembangunan didaerahnya masingmasing.

Ruang demokrasi itu terletak pada implementasi otonomi daerah yang diatur dalam UU No 32 tahun 2004 yang didalam penjelasan umumnya diterangkan bahwa pembentukan daerah pada dasarnya dimaksudkan untuk meningkatkan pelayanan publik guna mempercepat terwujudnya kesejahteraan masyarakat, disamping sebagai sarana pendidikan politik ditingkat lokal. maka pembentukan daerah harus mempertimbangkan beberapa fakto seperti kemampuan ekonomi, potensi daerah, luas wilayah, kependudukan, dan pertimbangan dari aspek sosial politik, sosial budaya, pertahanan, dan keamanan serta perimbangan dan syarat lain yang memungkinkan daerah itu dapat menyelenggarakan dan mewujudkan tujuannya. ${ }^{1}$

\footnotetext{
${ }^{1}$ Marsono dan P. Lingga, Petunjuk Penggunaan Pupuk. Jakarta; Penebar Swadaya, 2005 ) 27
} 
Oleh sebab itu otonomi daerah yang dijalankan selain bersifat nyata dan luas, tetap harus dilaksanakan secara tanggung jawab. maksudnya otonomi daerah harus dipahami sebagai perwujudan pertanggungjawaban konsekuensi pemberian hak dan kewenangan kepada kepala daerah dalam wujud tugas dan kewajiban yang harus dilaksanakan daerah. ide dasar pemberian otonomi kepada daerah sejatinya adalah untuk: pertama meningkatkan pelayanan dan kesejahteraan masyarakat yang semakin baik. kedua memelihara hubungan yang serasi antara pusat dengan daerah serta antar daerah dalam rangka menjaga kesatuan Negara Kesatuan RepublikIndonesia (NKRI). ketiga membangun kehidupan demokrasi, keadilan dan pemerintahan. ${ }^{2}$

Dalam rangka menjalankan tugas dan kewajiban tersebut, essensi mendasar dalam kebijakan pelaksanaan otonomi daerah adalah pemberian kewenangan yang ditetapkan batasan kewenangan yang dimiliki daerah untuk mengatur dan mengurus rumah tangganya sendiri. adanya pemberian kewenangan ini tentu merupakan essensi dasar dalam pelaksanaan otonomi daerah dimana daerah cukup mempunyai keluasan gerak dalam menggunakan potensinya, baik yang berasal dari daerahnya sendiri maupun pemberian pemerintah pusat sesuai dengan kebutuhan daerah dan kesejahteraan masyarakatnya. $^{3}$

Menurut Ramlan Subakti, ada dua alasan mengapa kepala daerah dan wakil kepala daerah dipilih secara langsung, pertama, agar lebih konsisten dengan sistem pemerintahan presidensial antara lain ditandai dengan pemilihan kepala pemerintahan secara langsung oleh rakyat. karena itu sebagaimana pada tingkat nasional presidan sebagai kepala pemerintahan dipilih langsung oleh rakyat melalui pemilihan umum, maka untuk kepala daerah otonom juga dipilih secara langsung oleh rakyat melalui pemilihan umum. dengan memilih secara langsung siapa yang memimpin suatu daerah rakyat yang berhak memilih dapat menentukan kepala daeran seperti apakah yang akan memimpin daerahnya, dan dapat menetukan pola serta arah kebijakan yang akan dibuat dan dilaksanakan untuk kesejahteraan daerah dan rakyatnya. Kedua, untuk menciptakan pembagian kekuasaan yang seimbang dan saling mengecek (check and balances) antara eksekutif dan legislatif. salah satu ciri pemerintahan yang menganut pembagian kekuasaan secara seimbang dan saling mengecek adalah baik eksekutif maupun legislatif sama-sama dipilih langsung oleh rakyat melalui pemilihan umum. keduanya memiliki kekuasaan yang seimbang dengan tugas dan kewenangan yang berbeda, keduanya saling mengontrol melalui pembuatan peraturan daeran dan APBD, keduanya memiliki legitimasi dari rakyat. kepala daerah dan wakil kepala daerah dipilih langsung oleh rakyat melalui pemilihan umum untuk menjamin agar kepala daerah menjadi mitra sejajar dengan DPRD. dengan begitu interaksi antara eksekutif dan legislatif diharapkan tidak saja

\footnotetext{
2 Leo Agustino, Dasar- dasar Kebijakan Publik. (Bandung: Alfabeta: 2008) 26

3 Hari Sabarno, Mamandu Otonomi Daerah Menjaga Kesatuan Bangsa(Sinar Grafika, Jakarta, 2007) 7-8
} 
dinamis tetapi produktif bagi kesejahteraan masyarakat daerah. ${ }^{4}$

Betapapun fenomena pilkada telah menjadi icon demokratisasi di Indonesia pasca orde baru. selain jumlah pemilihan langsung yang sangat banyak dalam satu tahun. pelaksanaan pilkada juga diwarnai isu konflik karena berbagai hal diantaranya: regulasi, kapasitas penyelenggaraan, persaingan antar pendukung pasangan calon, konflik internal partai pilkada juga menjadi pertanrungan antara para ( petahana) dalam mempertahankan kekuasaanformalnya untuk periode kedua. ${ }^{5}$ oleh karena itu, ruang demokrasi loka yang terbuka ini harus dimanfaatkan sebaik-baiknya. pilkada tidak dijadikan ruang konflik politik yang tidak menghasilkan apapun. namun pilkada adalah proses demokrasi yang mesti dijalankan dengan penuh harapan guna memilih kepala daerah yang sesuai dengan pilihan rakyat.

Melalui pilkada langsung, rakyat menentukan calon berdasarkan kredibilitas dan kapabilitasnya. publik daerah melihat rekam jejak dan pengabdian mereka pada daerah itu sendiri. atas dasar aspek inilah konstituen daerah akan memilihnya. apabila di eara yang transparan ini dengan dukungan media massa, rekam jejak figur dengan mudah dapat dilacak. bagaimanapun perjalanan proses karir sang kandidat, baik politik, pemerintahan, maupun karir bisnis akan tergambar dan menjadi representasi dari jati diri seorang figur kandidat.

Jawa Timur merupakan salah satu provinsi di pulau jawa yang terdiri dari 29 Kabupaten diantaranya: Bangkalan, Banyuwangi, Blitar, Bojonegoro, Bondowoso, Gresik, Jember, Lamongan, Lumajang, Madiaun, Magetan, Malang, Mojokerto, Nganjuk, Ngawi, Pamekasan, Pasuruan, Ponorogo, Probolinggo, Sampang, Sidoarjo, Situbondo, Sumenep, Trenggalek, Tuban, Tulungangung. dan 9 kota diantaranya : Batu, Blitar, Kediri, Madiun, Malang, Mojokerto, Pasuruan, Probolinggo, dan Surabaya. 'Sebagai salah satu daerah di Indonesia, Jawa Timur juga memiliki kewajiban untuk melaksanakan amanah undang-undang nomor 10 tahun 2016 tentang pemilukada di tahun 2018.

Meskipun Pemilukada Jawa Timur masih kurang beberapa bulan, namun geliat beberapa partai politik sebagai salah satu kendaraan pengusung calon gubernur dan wakil gubernur Jawa Timur sudah mulai kelihatan contohnya seperti dikutip dari laman detiknews rabu 31 Mei 2017 02:03 Wib bahwa Dewan Pengurus Wilayah Partai Kebangkitan Bangsa (DPW PKB) Jawa Timur yang sudah memantabkan diri untuk mengusung kader GP Ansor yang juga mantan wakil gubernur saat ini Saifullah Yusuf atau yang akrab dipanggil dengan sebutan Gus Ipul untuk maju dalam pilgub Jatim 2018.

Bergeser kesebelah timur yakni kabupaten Jember, kabupaten yang juga akan

\footnotetext{
${ }^{4}$ Ramlan Surbakti, Memahami Ilmu Politik, Jakarta: Gramedia Widya Sarana, 2006) 4-5

5 Sri Wardhani, Pembelajaran Kemampuan Pemecahan Masalab Matematika di SD. Yogyakarta: PKBPTK, 2010) 94-95

${ }^{6}$ https://id.wikipedia.org/wiki/Daftarkabupaten dan kota di_Jawa Timur
} 
turut berpartisipasi dalam melaksanakan pemilihan umum gubernur dan wakil gubernur Jawa Timur mendatang. DPC PKB Jember pun sepertinya sudah mempersiapkan strategi komunikasi politiknya untuk mengawal kebijakan DPW PKB Jawa Timur untuk mensukseskan kebijakannya dalam pemilu 2018 ini. maka dari itu untuk mengetahui strategi komunikasi politik seperti apakah yang dilakukan oleh DPC PKB Jember pada pemilukada 2018 perlu kiranya peneliti merumuskan pertanyaan penelitian yang lebih spesifik pada rumusan masalah.

\section{Metodologi Penelitian}

Pendekatan yang digunakan dalam penelitian ini adalah penelitian kualitatif. Penelitian kualitatif menggunakan metode kualitatif yaitu pengamatan, wawancara, atau penelaahan dokumen. Metode kualitatif ini digunakan karena, beberapa pertimbangan. Pertama, menyesuaikan metode kualitatif lebih mudah apabila berhadapan dengan kenyataan jamak. Kedua, metode ini menyajikan secara langsung hakikat hubungan antara peneliti dan responden. Ketiga, metode ini lebih peka dan lebih dapat menyesuaikan diri dengan banyak penajaman pengaruh bersama terhadap pola-pola yang dihadapi. ${ }^{7}$

Metode penelitian kualitatif adalah penelitian yang menggambarkan atau menjelaskan permasalahan yang ada dengan memberikan jawaban atas permasalahan yang dikemukakan. ${ }^{8}$ Metode penelitian ini merupakan penelitian lapangan (field research) Yang dapat juga dianggap sebagai pendekatan luas dalam penelitian kualitatif atau sebagai metode untuk mengumpulkan data kualitatif. Ide pentingnya adalah bahwa peneliti berangkat ke "lapangan" untuk mengadakan pengamatan tentang sesuatu fenomena dalam suatu keadaan alamiah.

Selain itu Penelitian ini memusatkan pada permasalahan-permasalahan yang ada pada saat penelitian dilakukan atau masalah-masalah yang bersifat aktual. Maka memecahkan masalah yang ada dilakukan dengan cara menggambarkan suatu keadaan data status fenomena berdasarkan fakta-fakta yang ada.

Dalam hal demikian, maka pendekatan ini erat kaitannya dengan pengamatan dan peran serta (participan observation) seorang peneliti lapangan, dan biasanya membuat catatan lapangan secara ekstensif lalu kemudian membuat kode-kode dan menganalisa dalam berbagai cara.

\section{Pembahasan}

\section{Strategi Komunikasi Politik PKB Kabupaten Jember menjelang Pemilukada Jawa Timur 2018}

Strategi komunikasi politik dalam menghadapi Pemilukada Jawa Timur 2018 merupakan perencanaan yang cermat yang disusun dan dilaksanakan oleh tim sukses partai politik maupun relawan yang memiliki tujuan mencapai kemenangan

${ }^{7}$ Moleong, Metodologi Penelitian Kualitatif. (Bandung: PT Remaja Rosdakarya, 2008) 9-10

8 Sugiyono, Metode Penelitian Kunatitatif Kualitatif dan ReDD.(Bandung: Alfabeta, 2008) 11 
atas sasaran yang ditentukan dalam Pemilukada. Sasaran merupakan tujuan dari apa yang ingin dicapai oleh tim kampanye untuk mencapai target dukungan yang diwujudkan dalam pemberian suara kepada partai politik atau salah satu calon tersebut.

Strategi komunikasi politik yang dilakukan oleh PKB Kabupaten Jember bertujuan untuk mempertahankan konstituen lama dan mendapatkan konstituen baru, dalam hal ini PKB Kabupaten Jember melakukan strategi komunikasi politik menurut segmentasi pemilih, segmentasi pemilih ini menurut Smiht dan Hirst yang dikutip oleh Firmanzah berguna untuk :

1. Membantu identifikasi kepentingan dan tujuan politik masing-masing masyarakat.

2. Membantu partai politik untuk lebih meningkatkan ketetapan program kerja dan isu politik di setiap kelompok masyarakat.

3. Membantu organisasi politik dalam mengembangkan program komunikasi politik. Mengingat masing-masing kelompok masyarakat memiliki cara berpikir yang berbeda.

4. Membantu dalam analisis atas persaingan politik, melihat jumlah yang ada di setiap segmen akan membantu organisasi politik bersangkutan dalam menghitung probabilitas untuk menang atau kalah.

5. Membantu organisasi politik untuk mengembangkan program marketing politik yng lebih tepat sasaran dan komprehensif (Firmanzah, 2011: 160).

Dalam hal ini PKB Kabupaten Jember menggunakan metode segmentasi pemilih Demografi yakni, konsumen politik yang dapat dibedakan berdasarkan umur, jenis kelamin, pendapatan, pendidikan, pekerjaan dan kelas sosial (Firmanzah, 2011: 161). Namun dilihat dari segi prakteknya PKB Kabupaten Jember hanya membedakan pemilih berdasarkan usia dalam menjalankan strategi komunikasi politiknya, berikut adalah langkah-langkah strategi komunikasi politik yang digunakan oleh PKB Kabupaten Jember dalam menarik simpati pemilih dari kalangan pemuda atau pemilih pemula dan orang tua.

\section{Strategi Komunikasi Politik PKB Kabupaten Jember di Kalangan Pemuda}

Berikut adalah kegiatan-kegiatan yang di lakukan oleh PKB Kabupaten Jember dalam rangka menggaet pemilih dari kalangan pemuda.

a. Ngopi Bareng PKB Jember yang bertempat di Alun-alun Kabupaten Jember 06-04-2017.

b. Melakukan buka bersama dengan kalangan mahasiswa yang tergabung dalam beberapa organisasi kampus yang bertempat di kantor DPC PKB Jember pada tanggal 10-062017.

c. Halal bihalah PKB Kabupaten Jember dengan masyarakat umum 2-07-2017.

Kegiatan-kegiatan tersebut bertujuan untuk menggaet pemilih dari kalangan pemuda seperti yang diungkapkan oleh Muhammad Hafidi S, Sos. selaku 
wakil ketua PKB Kabupaten Jember

“........kita banyak mengadakan kegiatan-kegiatan yang memang kita sasarannya kaum muda pertama Ngopi bareng PKB Jember kegiatan ini kami maksudkan untuk sosialisai partai dan memberikan pemahaman tentang PKB serta pemahaman-pemaham politik kepada kaum muda di Jember, kegiatan ngopi juga sudah menjadi kebiasaan rakyat indonesia dari mulai kalangan bawah sampai kalangan atas sekalipun sudah akrab dengan yang namanya ngopi, terus yang kedua buka bersama dengan mahasiswa, moment ini biasa kami lakukan untuk menjaga ukhuwah antara pemuda dengan partai karenea meraka (pemuda) suatu saat yang akan menggantikan yang sudah senior seperti saya ini, selain itu kami juga memberikan pemahaman politik yang baik terhadap mereka, dan yang terakhir halal bihalal, kegiatan halal bihalal ini kami lakukan biasanya setelah hari raya idul fitri selain menjaga tradisi islam yang dianjurkan untuk selalu menjaga tali silaturrahmi antar sesama ummat muslim kegiatan ini juga dalam rangka menjaga komunikasi kita dengan para pemuda dijember dengan semaksimal mungkin memanfaatkan moment-moment penting agar semakin dekat dan erat dengan PKB. sementara hal itu yang kami jalankan sampai saat ini untuk merekrut kaum - kaum muda di Jember, namun dengan demikian tidak menutup kemungkinan juga ada kegiatan yang lain juga yang akan kami lakukan kedepannya "(wawancara dengan Hafidi Tgl. 29 Juni 2017)

Kegiatan-kegiatan tersebut pun ikut dirasakan oleh beberapa kader muda PKB Kabupaten Jember, hal ini seperti yang diungkapkan oleh Agus Bonggo Pribadi yang juga salah satu anggota Gerakan Mahasiswa Satu Bangsa (Gemasaba) Kabupaten Jember.

“......dalam hal untuk membaur dengan masyarakat jaman sekarang yaitu kegiatan sepeda santai sambil ngopi, halal bihalal, buka bersama itukan termasuk juga kegiatan yang dilakukan untuk mendongkrak peningkatan suara PKB, apalagi ngopinya gratis. itukan sudah menjadi bukti bahwa dari DPC sangat ingin sekali suara PKB itu bisa menang terlebih dikalangan pemuda karena ini merupakan aset penting dimasa depan mas. ngopi misalnya siapa sih yang gak suka ngopi dari cowok sampai cewek sekarang sudah pada suka dan akrab dengan kata-kata ngopi meskipun kadang ketika ngopi mesennya bukan kopi tapi yang lain ya tapi itu terserah mereka, namun meski demikian mereka tetap menyebutnya dengan ngopi kok mas. kalau buka bersama dan halal bihalal sepertinya itu sudah biasa dilakukan oleh DPC karena menurut saya kegiatan tersebut merupak suatu hal positif karena dengan diadakannya kegiatan tersebut pengurus DPC dapat berinteraksi langsung dengan para pemuda yang ada di Jember itu juga kan untuk tetap menjaga komunikasi dengan kaum muda yang ada dijember ini"(wawancara dengan agus Tgl. 02 Juli 2017)

Beberapa kader PKB yang tergabung dalam sayap parpol PKB juga merasakan 
hal yang cukup positif dan menyambut baik kegiatan yang dapat merangkul pemuda - pemuda yang notabene akan menjadi penerus perjuangan kader-kader PKB yang sudah senior. Beni Abdillah menjelaskan :

" terus terang mas kami sangat mensupport kegiatan yang diadakan DPC ini karena saya selaku kaum muda menyadari betul bahwa konstituen kita dilingkup anak muda sekarang banyak yang suka ngopi di cafe, kedai, dan warung-warung dipinggir jalan. itu adalah kegiatan yang sangat tepat untuk merangkul pemilih pemula (pemuda) karena mereka akan terus berkembang dan bukan tidak mungkin mereka jugalah yang akan menjadi pemimpin PKB Jember dimasa depan" kalau kaitannya dengan halal bihalal dan buka bersama menurut saya ini strategi yang cukup baik dalam membidik kaum muda utamanya bagi mereka yang masih berstatus mahasiswa dan biasanya mas kegiatan ini banyak diikuti oleh kalangan aktivis intra kampus maupun ekstra kampus dan itu sangat mengena sekali karena sebagai aktivis mereka sudah terlatih untuk berbicara didepan umum dan mengkondisikan massa (Wawancara dengan Beni Abdillah Kamis 4 juni 2017)

\section{Strategi Komunikasi Politik PKB Kabupaten JemberUntuk Kalangan Pemilih Orang Tua}

Tidak hanya fokus kepada kaum muda saja dukungan juga pasti datang dari kalangan orang tua, untuk menggaet dukungan dari pemilih kalangan orang tua ini PKB Kabupaten Jember melakukan strategi komunikasi politik dengan terus membangun komunikasi yang linear dengan cara menjaga ikatan silaturahmi dengan tokoh masyarakat, ulama', pondok pesantren dan majelis taklim, majelis dzikir, majelis sholawat, serta kegiatan-kegiatan keagamaan lainnya.. Hal ini seperti yang diungkapkan oleh Ayub Junaidi selaku sekretaris DPC PKB Kabupaten Jember sebagai berikut:

"Bagi kami menjalin komunikasi dengan berbagai elemen masyarakat seperti kyai, tokoh masyarakat, ulama, pimpinan pondok pesantren, pimpinan majelis ta'lim, menjadi suatau keharusan tersendiri karena memang setuju atau tidak PKB basisnya disitu, kita kan partai yang dilahirkan dari rahim NU pada saat almarhum Gus Dur masih menjabat sebagai ketua umum PBNU. nah untuk komunikasi yang kami lakukan dalam menjaga konstituen utamanya para pemilih orang tua ada dua ma spertama bersifat formal seperti mengadakan kegiatan dengan menempatkan disalah satu pesantren di Jember atau dengan menghadiri majelis-majelis taklim milik NU, kedua komunikasi yang bersifat tidak formal seperti berkunjung (sowan) ke beberapa kiai panutan dijember untuk sekedar say hallo, sharing, dan bahkan meminta restu dari para kiai perihal kegiatan-kegiatan yang akan kami lakukan, karena kita sadar betul bahwa PKB ini dibentuk oleh NU yang dihuni oleh para Kiai dan ulama jadi kita harus kesana dulu agar apa yang kita lakukan ini bermanfaat bagi masyarakat secara luas" (wawancara ayub junaidi Tgl 03 Juli 2017)

Kalimat yang samapun diungkapkan oleh Amin Thohari yang menjabat 
sebagai wakil ketua:

“.........di samping itu juga kita tetap menggunakan komunikasi melalui para tokoh masyarakat dan ulama' atau para kyai-kyai yang ada didesa-desa Ya karena memang pemilih-pemilih kita ada disitu dan jangan salah juga mereka merupakan penyumbang suara terbanyak lho dan bahkan ada beberapa kyai didesa mengatakan sekali PKB merekea tidak akan pindah ke yang lain. selain hal tersebut hampir dari seluruh partai-partai yang berbasis massa Islam peran tokoh sangat tinggi, Tapi khususnya tokoh2 tua yah" maka dari itu kita akan selalu menjaga marwah PKB sebagai partai yang peduli dengan rakyat dengan selalu dekat dengan ulama yang sudah pasti pemikiran dan tujuannya hanya untuk kesejahteraan ummat (wawancara Amin Thohari Tgl. 12 Juli 2017)

\section{Saluran-Saluran Komunikasi Politik PKB Kabupaten Jember menjelang Pemilukada Jawa Timur 2018}

Menjelang pemilukada Jawa Timur 2018 PKB Kabupaten Jember menggunakan 3 dari 5 saluran-saluran komunikasi politik yang ada.

a. Saluran Komunikasi Politik Struktur Tradisional

Saluran komunikasi politik struktur sosial tradisional, yaitu dimana arus komunikasi yang ditentukan oleh posisi sosial pihak yang berkomunikasi,dalam hal ini PKB Kabupaten Jember, membangun komunikasi dan silaturahmi dengan tokoh masyarakat, ulama, pondok pesantren dan majelis taklim.

b. Saluran Komunikasi Politik Input

Saluran komunikasi politik input, yakni saluran yang memanfaatkan berbagai pihak yang biasanya memberikan masukan (input) politik. Dalam konteks ini PKB Kabupaten Jember menjalin komunikasi dengan berbagai Ormas di antaranya Pengurus Cabang Nahdlatul Ulama (PCNU) Kabupaten Jember, GP Ansor, IPNU dan IPPNU Kabupaten Jember. Hal ini dibuktikan dengan adanya pertemuan yang dilakukan oleh PKB Kabupaten Jember dengan MWC NU pada tanggal 5 Mei 2017.

\section{c. Saluran Komunikasi Politik Melalui Media Massa}

Saluran Komunikasi Politik media massa, dalam hal ini PKB Kabupaten Jember mengekspos kegiatan-kegiatan dan program-program mereka melalui media massa seperti Facebook, ucapan selamat hari raya idul fitri dibanner, dan lain-lain. Seperti yang di ungkapkan oleh Miftahul Ulum selaku ketua PKB Kabupaten Jember:

"Untuk saluran komunikasi poiltiknya selain komunikasi secara langsung dengan konstituen kita tetap harus berimbang dan memanfaatkan kecanggihan tekhnologi yang ditawarkan di era sekarang dengan cara kita terus mengekspos setiap kegiatan-kegiatan yang kita lakukan agar informasi dapat tersampaikan secara luas, bahkan kita memiliki orang khusus yang tugasnya untuk membesarkan PKB melaui media-media digital, kalau dahulu kita ekplorasinya melalui banner-banner yang dipasang dijalan-jalan sekarang 
jamannya sudah lebih maju sehingga dapat memudahkan kami dalam memberikan informasi kegiatan yang kami lakukan kepada masyarakat melalui media sosial Facebook, whataps, instagram , dll'. selain mudah media ini juga menjadi media alternatif ditengah besarnya dana kampanye. dan jangan salah kegiatan mengeksplore dimedia sosial itu juga komunikasi tho mas. nah kegiatan yang kita ekspos tersebut betujuan untuk memberikan informasi kepada masyarakat bahwa PKB Jember tetap eksis dan berdiri digarda depan dalam mengawal kepentingan masyarakat hal ini juga menjadi pesan yang kita tanamkan pada masyarakat bahwa kita harusnya memilih PKB sebagai kendaraan politik kita" (wawancara dengan Miftahul Ulum Tgl. 16 Juli 2017).

Beragam strategi komunikasi politik yang dilakukan DPC PKB Kabupaten Jember adalah sebuah bentuk ikhtiar untuk menjaga performa komunikatif mereka, dan diharapkan dapat terus menjaga eksistensi atau keberlangsungan PKB Kabupaten Jember ditengah kerasnya persaingan partai dan munculnya banyak partai politik baru.

\section{Performa Komunikatif PKB Kabupaten Jember}

Performa komunikatif merupakan sesuatu yang harus dilakukan oleh setiap partai politik, ini dilakukan supaya partai politik dapat menjaga eksistensinya sebagai suatu organisasi politik. Performa adalah metafora yang menggambarkan proses simbolik pemahaman akan perilaku manusia dalam sebuah organisasi, performa organisasi seringkali memiliki unsur teatrikal, di mana baik supervisior maupun karyawan (kader partai dalam hal ini) memilih untuk mengambil peranan atau bagian tertentu dalam organisasi mereka. Dalam menjaga performa, tentu saja terkait dengan citra dan agenda kerja, oleh sebab itu PKB Kabupaten Jember melakukan beberapa upaya agar dapat menjaga eksistensinya dalam dunia politik.

Berikut adalah langkah-langkah atau kegiatan-kegiatan yang dilakukan oleh PKB Kabupaten Jember yang bertujuan untuk tetap menjaga performa mereka dalam menghadapi Pemilukada Jawa Timur 2018.

1. Performa ritual, yaitu merupakan semua performa komunikasi yang terjadi secara teratur dan berulang (Heryanto, 2010: 326). ini menyangkut semua hal yang dilakukan oleh PKB Kabupaten Jember menjelang Pemilukada Jawa Timur 2018.

2. Performa sosial, yakni Performa sosial merupakan perpanjangan sikap santun dan kesopanan untuk mendorong kerja sama diantara anggota organisasi (Heryanto, 2010: 326). Dalam hal ini adalah langkah-langkah yang dilakukan oleh PKB Kabupaten Jember dalam berkerja sama dengan para kader dan jaringan organisasi PKB Kabupaten Jember di tingkat kecamatan dan ranting.

3. Performa politis, yakni perilaku organisasi yang mendemonstrasikan kekuasaaan dan kontrol, yakni menyangkut cara mendapatkan konstituen baru 
dan mempertahankan konstituen lama.

4. Performa enkulturasi, dalam performa ini, PKB Kabupaten Jember memberikan fasilitas, pengetahuan dan keahlian kepada kader-kadernya dalam rangka meningkatkan komunikasi politik dan bagaimana menjadi politisi yang dapat mencapai jabatan publik serta mensosialisasikan program-program partai kepada konstituennya.

\section{Kesimpulan}

Menjelang pemilukada Jawa Timur 2018 PKB Jember melakukan beberapa strategi komunikasi politik, strategi komunikasi politik yang digunakan diantaranya: Strategi Komunikasi Politik PKB Kabupaten Jember dikalangan Pemuda. Berikut adalah kegiatan-kegiatan yang di lakukan oleh PKB Kabupaten Jember dalam rangka menggaet pemilih dari unsur anak muda :1) Ngopi Bareng PKB Jember yang bertempat di Alun-alun Kabupaten Jember 06-04-2017. 2) Melakukan buka bersama dengan kalangan mahasiswa yang tergabung dalam beberapa organisasi kampus yang bertempat di kantor DPC PKB Jember pada tanggal 10-062017. 3) Halal bihalah PKB Kabupaten Jember dengan masyarakat umum 2-07-2017.

Strategi Komunikasi Politik PKB Kabupaten Jember Untuk Kalangan Orang Tua Untuk menggaet dukungan dari pemilih kalangan orang tua PKB Kabupaten Jember melakukan strategi komunikasi politik dengan membangun komunikasi dan silaturahmi dengan tokoh masyarakat, ulama, pondok pesantren dan majelis taklim.

Performa ritual, yaitu merupakan semua performa komunikasi yang terjadi secara teratur dan berulang ini menyangkut semua hal yang dilakukan oleh PKB Kabupaten Jember menjelang Pemilukada Jawa Timur 2018 dianataranya 1)Performa sosial, yakni Performa sosial merupakan perpanjangan sikap santun dan kesopanan untuk mendorong kerja sama diantara anggota organisasi (Heryanto, 2010: 326). Dalam hal ini adalah langkah-langkah yang dilakukan oleh PKB Kabupaten Jember dalam berkerja sama dengan para kader dan jaringan organisasi PKB Kabupaten Jember di tingkat kecamatan dan ranting. 2) Performa politis, yakni perilaku organisasi yang mendemonstrasikan kekuasaaan dan kontrol, yakni menyangkut cara mendapatkan konstituen baru dan mempertahankan konstituen lama. 3) Performa enkulturasi, dalam performa ini, PKB Kabupaten Jember memberikan fasilitas, pengetahuan dan keahlian kepada kader-kadernya dalam rangka meningkatkan komunikasi politik dan bagaimana menjadi politisi yang dapat mencapai jabatan publik serta mensosialisasikan program-program partai kepada konstituennya. 


\section{Daftar Pustaka}

Agustino, Leo. Dasar-dasar Kebijakan Publik. (Bandung; Alfabeta, 2008)

Alisson, Michael \& Kaye Jude, Strategic Planing Non Profit Organizazion: A Practical Guid And Workbook, 1997

Alwi Hasan, dkk. Kamus Besar Bahasa Indonesia. (Jakarta: Departemen Pendidikan Nasional Balai Pustaka, 2005)

Anwar, Arifin, Pencitraan dalam Politik. (Jakarta: Pustaka Indonesia, 2006)

Ardial, Komunikasi Politik(Jakarta; Indeks, 2010)

Ariani, N. dan Haryanto, D ,Pembelajaran Multimedia di Sekolah, (Jakarta: Prestasi Pustaka, 2010)

Arikunto, Suharsimi. Prosedur Penelitian Suatu Pendekatan Praktik. (Jakarta: Rineka Cipta, 1998)

Budiardjo, Miriam. Dasar-dasar Ilmu Politik. (Jakarta: PT. Gramedia, 2008)

Cangara, Hafied. Komunikasi Politik. (Jakarta: PT. Raja Grafindoo Persada, 2009)

Effendy, Onong Uchjana. Ilmu Komunikasi (Teori dan Praktek). (Bandung: PT. Remaja Rosdakarya, 2007)

Hari Sabarno, Mamandu Otonomi Daerah Menjaga Kesatuan Bangsa (Jakarta; Sinar Grafika, 2007)

Marsono dan P. Lingga. Petunjuk Penggunaan Pupuk. (Jakarta; Penebar Swadaya, 2005)

Moleong, Lexy. Metodologi Penelitian Kualitatif:: Bandung; PT Remaja Rosdakarya 2008)

Nimmo, Dan, Komunikasi Politik Komunikator, Pesan, dan Media. (Bandung:PT Rempaja Rosdakarya, 2005)

Sugiyono, Metode Penelitian Kunatitatif Kualitatif dan R $\sigma D$. (Bandung Alfabeta, 2008)

Surbakti, Ramlan, Memahami Ilmu Politik, (Jakarta: Gramedia Widya Sarana, 2006)

Wardhani, Sri dkk. Pembelajaran Kemampuan Pemecahan Masalah Matematika di SD.

(Yogyakarta: PKBPTK, 2010) 